\title{
Conservation Genetics of an ENDANGered CyCAD, DiOON SONORENSE (ZAMIACEAE): IMPLICATIONS FROM VARIATION OF CHLOROPLAST DNA
}

\author{
José Said Gutiérrez-Ortega ${ }^{1,3}$, Tadashi Kajtia and Francisco E. Molina-Freaner ${ }^{2}$ \\ 'Department of Biology, Graduate School of Sciences, Chiba University, Inage-ku, Chiba, Japan \\ ${ }^{2}$ Departamento de Ecología de la Biodiversidad, Instituto de Ecología, \\ Universidad Nacional Autónoma de México, Hermosillo, Sonora, Mexico \\ ${ }^{3}$ Corresponding author: josesgo@chiba-u.jp
}

\begin{abstract}
The endemic species Dioon sonorense comprises the northernmost group of populations of Dioon, in Sonora, Mexico. Although it is endangered, only the southern populations are protected within a preservation area, while the remaining populations have not been taken into account in management plans or genealogical studies. Describing the intraspecific genealogy and the geographical structure of the genetic variation of $D$. sonorense may help in the identification of units for further conservation. Therefore, the main objective of this study was to describe the intraspecific genealogy of populations throughout the range of distribution of the endangered species $D$. sonorense, using haplotypes of the trnL-F spacer of the cpDNA. In addition, the levels of diversity of the employed molecular marker were estimated. Low levels of variability were recorded and at least two evolutionary units, corresponding to each haplotype, were identified as components of the species. The inclusion of northern populations into conservation programs is recommended. In order to integrate these findings to the genealogy of genus Dioon, trnL-F sequences of all the remaining species were merged and analyzed. An ancestral haplotype with wide distribution was detected in several species and one haplotype in D. sonorense was found shared with its sister species, D. tomasellii. This work represents a first attempt to reconcile a genealogical approach in the identification of important centers of genetic diversity of Mexican cycads.
\end{abstract}

Key words: chloroplast DNA, conservation genetics, Dioon sonorense, endangered species.

Resumen: La especie endémica Dioon sonorense representa el grupo de poblaciones más norteño para el género Dioon, en Sonora, México. A pesar de su estatus en peligro de extinción, sólo las poblaciones del sur están protegidas dentro de un área de conservación, mientras que las poblaciones restantes no han sido consideradas en los planes de manejo o en estudios genealógicos. La descripción de la genealogía intraespecífica y la estructura geográfica de la variación genética de $D$. sonorense puede ayudar en la identificación de unidades evolutivas para su posterior conservación. Por lo tanto, el objetivo principal de este estudio fue describir la genealogía intraespecífica de las poblaciones de $D$. sonorense a lo largo de su rango de distribución, usando los haplotipos del espacio $t r n L-F$ del ADNcp. Además, se estimaron los niveles de diversidad genética usando este marcador molecular. Se obtuvieron niveles bajos de variabilidad y se identificaron al menos dos unidades evolutivas, correspondientes a cada haplotipo que componen a la especie. Se recomienda la inclusión de las poblaciones del norte en los programas de conservación. Con el fin de integrar estos hallazgos en el contexto de la genealogía del género Dioon, las secuencias del espacio $\operatorname{trn} L-F$ de todas las especies restantes fueron combinadas y analizadas. Se detectó un haplotipo ancestral con una amplia distribución en varias especies y un haplotipo en $D$. sonorense se encontró compartido con su especie hermana, $D$. tomasellii. Este trabajo representa un primer intento de reconciliar un enfoque genealógico con la identificación de centros importantes de diversidad genética en las cícadas mexicanas. Palabras clave: ADN del cloroplasto, Dioon sonorense, especie en peligro de extinción, genética de la conservación.

$\mathbf{M}$ exico shelters a great diversity of cycads, and all of them are threatened with extinction and subject to conservation efforts (Osborne et al., 2012). Fifty-four species of the genera Zamia, Ceratozamia, and Dioon are distributed within Mexico, while the latter two genera are endemic to Mexico and Central America. The center of diversification of Dioon is assumed to be in Mexico (Moynihan, 2008), where thirteen Dioon species are found, while only one more species is found within both Honduras and Nicaragua (Bonta et al., 2006). 
Dioon sonorense (De Luca, Sabato \& Vázq. Torres) Chemnick, T.J.Greg. \& S.Salas-Mor. is the species with the northernmost range of distribution, in the Sierra Madre Occidental and neighbor mountain ranges in the states of Sonora and Sinaloa, Mexico (Whitelock, 2002; González-Astorga et al., 2009). Only four populations of $D$. sonorense, labeled as Mazatán, El Novillo, Nuri, and Álamos, have been reported in population genetic studies (González-Astorga et al., 2008, 2009); however, the exact number of populations and their status (number of individuals and present condition) are still uncertain. Although its endangered status is recognized by international institutions (Endangered A2ce+4c; C1 ver 3.1; IUCN, 2013), and by federal laws (Category P with MER method; SEMARNAT, 2010), only the southern populations are protected within a preservation area (Área de Protección de Flora y Fauna Sierra de Álamos-Río Cuchujaqui), whereas the remaining populations are still being excluded from federal management plans (CONANP, 2013) or genealogical analyses.

Although conservation programs are generally founded on morphological taxonomic units, in some cases, morphological traits lead to little or no recognition of intraspecific evolutionary groups (Taberlet and Bouvet, 1994). For that reason, examining patterns of genetic diversity has become an important facet for conservation (Matocq and Villablanca, 2001). Previous studies have described allozyme variation of six Dioon species (González-Astorga et al., 2003, 2005, 2008, 2009; Cabrera-Toledo et al., 2008). In combination, the mean values of alleles per locus (A), expected heterozygocity $(\mathrm{He})$ and percentage of polymorphic loci $(\mathrm{P})$ are 1.8, 0.286, and 70.2, respectively (Piñero et al., 2008). For $D$. sonorense, those values were greater $(\mathrm{A}=2, \mathrm{He}=$ 0.314, P = 81.6; González-Astorga et al., 2008, 2009), and showed low levels of differentiation among populations $\left(\mathrm{G}_{\mathrm{st}}\right.$ $=0.151)$. However, the methods used were unable to detect genealogical differentiation which could distinguish evolutionary units. Also, the number of populations surveyed in those studies was limited and only covered a part of the distribution. From a different perspective, since the chloroplast genome of cycads is maternally inherited (Cafasso et al., 2001) and has low rates of neutral substitution (Ravi et al., 2008), low levels of genetic variation at the intraspecific level are expected and can be directly correlated with historical dispersal of the seeds, allowing for the distinction of sets of populations which have a common recent history and might be considered as evolutionarily significant units (ESU) for conservation (Moritz, 1994).

Identifying evolutionary units may also help solve the relationships within the genus Dioon. Although D. sonorense is commonly shown as sister species to D. tomasellii, the phylogenetic relationships among the other Dioon species still remain unresolved due to low levels of interspecific differentiation and low number of analyzed samples per species in previous phylogenetic studies (Moretti et al., 1993; González et al., 2008; Moynihan, 2008). Sampling schemes that consider different intraspecific groups might provide a better resolution in the understanding of the evolution of this genus. Also, in view of the low levels of variation among Dioon species, instead of using a phylogenetic approach aimed to obtain resolution of species trees, a genealogical perspective describing the history of the cpDNA may provide better description of the evolutionary relationships (Rosenberg and Nordborg, 2002).

The main objective of this study was identifying evolutionary units for further conservation, based on the resolution of the intraspecific genealogy of the cpDNA of the species Dioon sonorense. Moreover, in an attempt to glimpse the genealogical relationships of the detected haplotypes at interspecific level, the obtained data were merged with homologous sequences of other Dioon species.

Table 1. Estimated number of individuals per population based on field observation (Est), number of sampled (Sam) and analyzed (Ana) individuals per population, haplotype detected (Hap), estimated values of haplotype and nucleotide diversity $(\mathrm{Hd}, \pi)$, Watterson index $(\theta-W)$ and Tajima's D (D) are listed. ${ }_{\mathrm{i}}=$ parameter considering one indel, SA. = Sierra de Álamos, SM. = Sierra de Mazatán.

\begin{tabular}{|c|c|c|c|c|c|c|c|c|c|c|}
\hline Population & Est & Sam & Ana & Hap & $\mathrm{Hap}_{\mathrm{i}}$ & $\mathrm{Hd}$ & $\mathrm{Hd}_{\mathrm{i}}$ & $\pi$ & $\theta-W$ & $\mathrm{D}$ \\
\hline 1) Choquincahui & 75 & 38 & 10 & B & B & 0 & 0 & 0 & - & - \\
\hline 2) SA. Cañada del Altar & 50 & 35 & 10 & B & B & 0 & 0 & 0 & - & - \\
\hline 3) Nuri & 8 & 8 & 8 & A & $\mathrm{Ai}$ & 0 & 0 & 0 & - & - \\
\hline 4) Bacanora & 60 & 33 & 10 & A & $\mathrm{Ai}$ & 0 & 0 & 0 & - & - \\
\hline 5) El Novillo-Bacanora & 7 & 7 & 6 & A & A & 0 & 0 & 0 & - & - \\
\hline 6) El Novillo & 2 & 2 & 2 & A & A & 0 & 0 & 0 & - & - \\
\hline 7) SM. Peñón de las Iglesias & 150 & 60 & 11 & A & A & 0 & 0 & 0 & - & - \\
\hline 8) SM. Cañada de la Leona & 100 & 45 & 10 & A & A & 0 & 0 & 0 & - & - \\
\hline 9) SM. Rancho La Cueva & 75 & 30 & 10 & A & A & 0 & 0 & 0 & - & - \\
\hline All populations combined & 527 & 258 & 77 & A, B & $A, A i, B$ & $\begin{array}{l}0.390 \pm \\
0.049\end{array}$ & 0.6295 & $\begin{array}{l}0.0004 \pm \\
0.00005\end{array}$ & $\begin{array}{l}0.00021 \pm \\
0.00021\end{array}$ & $\begin{array}{l}1.10825 \\
P>0.10\end{array}$ \\
\hline
\end{tabular}




\section{Conservation genetics of DioON SONORENSE}

Table 2. Dioon species and localities of specimens analyzed. When necessary, the identification number of the specimens recorded by González et al. (2008) are indicated in parenthesis with their GenBank access number. ID = identification number of specimen deposited in Jardín Botánico F. J. Clavijero, $\mathrm{N}=$ number of samples, Hap = detected haplotypes, ${ }^{a}=$ sequence obtained from a sample received from the Jardín Botánico $\mathrm{F}$. J. Clavijero, ${ }^{b}=$ identical obtained sequence from a specimen that was also analyzed by González et al. (2008), NI = sample from Jardín Botánico F. J. Clavijero without ID, U/D = unavailable data.

\begin{tabular}{|c|c|c|c|}
\hline Taxon and original locality & $\mathbf{N}$ & Hap & ID and GenBank sequence accession \\
\hline \multicolumn{4}{|l|}{ D. sonorense (De Luca, Sabato \& Vázq.Torres) } \\
\hline \multicolumn{4}{|l|}{ Chemnick, T.J.Greg. \& S.Salas-Mor. } \\
\hline 1) Choquincahui, Sonora & 10 & $\mathrm{~B}$ & \\
\hline 2) Álamos, Sonora & 12 & $\mathrm{~B}$ & (A) DQ926776; (B) DQ926777 \\
\hline 3) Nuri, Sonora & 8 & A & \\
\hline 4) Bacanora, Sonora & 10 & A & \\
\hline 5) El Novillo-Bacanora, Sonora & 6 & A & \\
\hline 6) El Novillo, Sonora & 2 & A & \\
\hline 7) Peñón de las Iglesias, Sierra de Mazatán, Sonora & 11 & A & \\
\hline 8) Cañada de la Leona, Sierra de Mazatán, Sonora & 10 & A & \\
\hline 9) Rancho La Cueva, Sierra de Mazatán, Sonora & 10 & A & \\
\hline \multicolumn{4}{|l|}{ D. angustifolium Miq. } \\
\hline 10) Rancho Muralla, Linares, Nuevo León & 2 & $\mathrm{C}$ & (A) DQ926750; (B) DQ926751 \\
\hline \multicolumn{4}{|l|}{ D. argenteum T.J.Greg, Chemnick, Salas-Mor. \& Vovides } \\
\hline 11) San Pedro Yolox, Oaxaca & 4 & $\mathrm{D}, \mathrm{E}$ & (A)DQ926752; (B) DQ926753; (C) DQ926754; (D)a U/D \\
\hline \multicolumn{4}{|l|}{ D. califanoi De Luca \& Sabato } \\
\hline 12) Teotitlán, Oaxaca & 2 & $\mathrm{C}$ & $(A)^{a, b}$ DQ926755; (B) DQ926756 \\
\hline \multicolumn{4}{|l|}{ D. caputoi De Luca, Sabato \& Vázq.Torres } \\
\hline 13) Caltepec, Puebla & 2 & $\mathrm{C}$ & (A) DQ926757; (B) DQ926758 \\
\hline 14) San Luis Atolotitlán, Puebla & 1 & $\mathrm{C}$ & $(\mathrm{NI})^{\mathrm{a}} \mathrm{N} / \mathrm{D}$ \\
\hline \multicolumn{4}{|l|}{ D. edule Lindl. } \\
\hline 15) Monte Obscuro, Veracruz & 2 & $\mathrm{~F}, \mathrm{G}$ & (A) DQ926759; (B) DQ926760 \\
\hline 16) Municipio Casas, Tamaulipas & 1 & $\mathrm{H}$ & (C) DQ926761 \\
\hline 17) Tamasopo, San Luis Potosí & 1 & I & (D) DQ926762 \\
\hline 18) Actopan, Veracruz & 1 & $\mathrm{C}$ & (E) DQ926763 \\
\hline 19) Coatepec, Veracruz & 1 & J & $(\mathrm{F})^{\mathrm{a}, \mathrm{b}}$ DQ926764 \\
\hline \multicolumn{4}{|l|}{ D. holmgrenii De Luca, Sabato \& Vázq.Torres } \\
\hline 20) San Gabriel Mixtepec, Oaxaca & 3 & $\mathrm{~K}, \mathrm{~L}$ & (A) DQ926765; (B) DQ926766; (C)a N/D \\
\hline \multicolumn{4}{|l|}{ D. mejiae Standl. \& L.O.Williams } \\
\hline 21) Gualaco, Honduras & 1 & M & (A) DQ926767 \\
\hline 22) Esquipulas, Honduras & 1 & $\mathrm{C}$ & (B) DQ926768 \\
\hline 23) Olanchito, Honduras & 1 & $\mathrm{C}$ & (C) DQ926769 \\
\hline \multicolumn{4}{|l|}{ D. merolae De Luca, Sabato \& Vázq.Torres } \\
\hline 24) Jiquipilas, Chiapas & 2 & $\mathrm{~N}$ & (A) DQ926770; (B) DQ926771 \\
\hline \multicolumn{4}{|l|}{ D. purpusii Rose } \\
\hline 25) Cuicatlán, Oaxaca & 2 & $\mathrm{C}$ & (A) DQ926772; (B) DQ926773 \\
\hline 26) Pápalo, Oaxaca & 1 & $\mathrm{O}$ & $(S)^{a} U / D$ \\
\hline \multicolumn{4}{|l|}{ D. rzedowskii De Luca, A. Moretti, Sabato \& Vázq.Torres } \\
\hline 27) San Bartolomé, Oaxaca & 2 & $\mathrm{C}, \mathrm{P}$ & (A) DQ926774; (B) DQ926775 \\
\hline \multicolumn{4}{|l|}{ D. spinulosum Dyer \& Eichler } \\
\hline 28) San Juan Bautista Tuxtepec, La Mina, Oaxaca & 1 & Q & (B) DQ926778 \\
\hline \multicolumn{4}{|l|}{ D. stevensonii Nicolalde-Morejón \& Vovides } \\
\hline 29) El Escondido, Guerrero & 1 & $\mathrm{R}$ & $(J)^{\mathrm{a}} \mathrm{U} / \mathrm{D}$ \\
\hline \multicolumn{4}{|l|}{ D. tomasellii De Luca, Sabato \& Vázq.Torres } \\
\hline 30) Cabo Corrientes, Jalisco & 1 & $\mathrm{C}$ & (A) DQ926779 \\
\hline 31) Zirándaro, Guerrero & 1 & $\mathrm{C}$ & (C) DQ926780 \\
\hline 32) Compostela, Nayarit & 1 & A & $(F)^{a} \mathrm{U} / \mathrm{D}$ \\
\hline
\end{tabular}




\section{Materials and methods}

Sampling. One leaflet per individual of each patch from nine populations of Dioon sonorense was sampled throughout the range of distribution in Sonora, Mexico (Table 1). The names of the localities were recorded and the number of individuals was estimated by direct observation. For additional analyses, eight samples of other Dioon species (including information of their original localities) were received from the "Colección Nacional de Cycadas" of Jardín Botánico Francisco Javier Clavijero, Instituto de Ecología, A.C., Xalapa, Veracruz, Mexico (SEMARNAT Colección Científica VER.-FLO-228-09-09; Table 2).

DNA isolation, amplification, and sequencing. For each sample, total DNA was isolated following the protocol by Doyle and Doyle (1987). In a preliminary survey designed to detect variable sites on Dioon sonorense, double stranded DNA of non-coding regions of the chloroplast DNA (cpDNA) was examined using at least one sample per population. The original references and primer sequences are listed in Appendix 1 . The regions atpB-rbcL (765 bp), atpF-H (565 bp), trnT-L (456 bp), trnH-psbA (582 bp), and rpl20-rps 12 (770 bp), showed no polymorphisms. The intron $\operatorname{trnL}$ and the intergenic spacer trnL-trnF (978 bp) showed one transversion and one indel on a mononucleotide repeat region; and when possible, at least ten individuals per population were randomly selected for further analysis. Polymerase Chain Reactions (PCRs) were performed in a Takara PCR Thermal Cycler Dice at $10 \mu \mathrm{L}$ volumes containing 10X EX Taq buffer (Takara), $2.5 \mathrm{mM} \mathrm{MgCl} 2,250 \mu \mathrm{M}$ of each dNTP, $0.4 \mu \mathrm{M}$ of each primer, $0.2 \mathrm{U}$ rTaq DNA Polymerase (Takara) and $1 \mu \mathrm{L}$ of template DNA. Thermocycling conditions were $95{ }^{\circ} \mathrm{C}$ for $1 \mathrm{~min} ; 35$ cycles of $95{ }^{\circ} \mathrm{C}$ for $45 \mathrm{sec}, 51{ }^{\circ} \mathrm{C}$ for $45 \mathrm{sec}$ and $72{ }^{\circ} \mathrm{C}$ for $1 \mathrm{~min}$; and a final extension at $72{ }^{\circ} \mathrm{C}$ for $5 \mathrm{~min}$. Amplification products were confirmed by electrophoresis in $0.8 \%$ agarose gel with ethidium bromide $1 \%$. Purification of PCR products was carried out using ExoSAP-IT (USB Corp., Cleveland, Ohio, USA) and cycle sequencingreactions were produced using BigDye Terminator v.3.1 Cycle Sequencing Kit (Applied Biosystems) following the manufacturer's instructions. Sequencing-reaction products were purified by ethanol precipitation and Sanger sequencing was determined with an ABI 3500 DNA sequencer (Applied Biosystems).

Parameter estimation. All sequences were edited using the Bioedit v7.1.11 software (Hall, 1999). Two matrix data were built for parallel analyses: one including only Dioon sonorense sequences obtained in this study; the second one included the $D$. sonorense sequences, the eight samples of the other Dioon species received from Jardín Botánico Francisco Javier Clavijero, and the sequences of the $\operatorname{trn} L-F$ spacer of cpDNA from González et al. (2008), published in GenBank. The original localities of the specimens were checked in Appendix 1 of that publication and located with Google Earth (Google Inc., 2013). In both sets of data, the alignment of sequences was performed with the Clustal X program (Thompson et al., 1997) with minimal manual adjustments (Table 2).

On Dioon sonorense, the DnaSP v5.10.01 software (Librado and Rozas, 2009) was used to calculate nucleotide diversity $(\pi)$, haplotype diversity $(H d)$, haplotype diversity considering indel $\left(H d_{\mathrm{i}}\right)$, the Watterson estimator $(\theta-W)$, and Tajima's statistical test $(D)$. Also, the haplotype corresponding to each sample was identified using the Generate Haplotype Data command. All these parameters were estimated for both disregarding and considering the indel in the mononucleotide repeat region (site 657). For the alignment data of all Dioon sequences, 118 sites with at least one ambiguous character (base $\mathrm{N}$ ) in the borrowed sequences from GenBank were considered as equal to the consensus. Because the length of the sequences from GenBank was shorter in the 3' extreme, the total length of the alignment was cut in order to fit as many sequences as possible. Since consideration of mononucleotide repeat regions is not suitable for genealogical studies (Selkoe and Toonen, 2006), the mononucleotide repeat in the alignment data of total samples of Dioon was deleted (12 bp starting from site 657). The haplotype corresponding to each sample was identified using the DnaSP v5.10.01 software (Librado and Rozas, 2009) with the Generate Haplotype Data command. Also, the TCS v1.18 software (Clement et al., 2000) was used to generate a parsimonious net of haplotypes at $95 \%$ of confidence, considering gaps as fifth state.

\section{Results}

Field work and observations. Nine localities along the range of distribution of the endangered cycad Dioon sonorense were surveyed: the four reported by González-Astorga et al. (2008, 2009), and five more populations. All the patches found were sampled, and the estimated number of individuals in each population is listed in Table 1.

Nucleotide and haplotype diversity within Dioon sonorense. A total of 4,115 bp of non-coding regions of the cpDNA of $D$. sonorense were explored in the preliminary analysis in order to detect intraspecific variability. Only two polymorphic sites (one transversion and one mononucleotide repeat indel) were found within the intron $\operatorname{trn} L$ and the intergenic spacer $\operatorname{trn} L-\operatorname{trn} F$ (978 bp). For further analysis, a total of 77 sequences of this region were obtained from nine populations of $D$. sonorense. Haplotype diversity considering indel $\left(H d_{\mathrm{i}}\right)$ and nucleotide diversity $(\pi)$ were estimated to be 0.6295 and 0.0004 , respectively (Table 1 ). All the populations were monomorphic. 


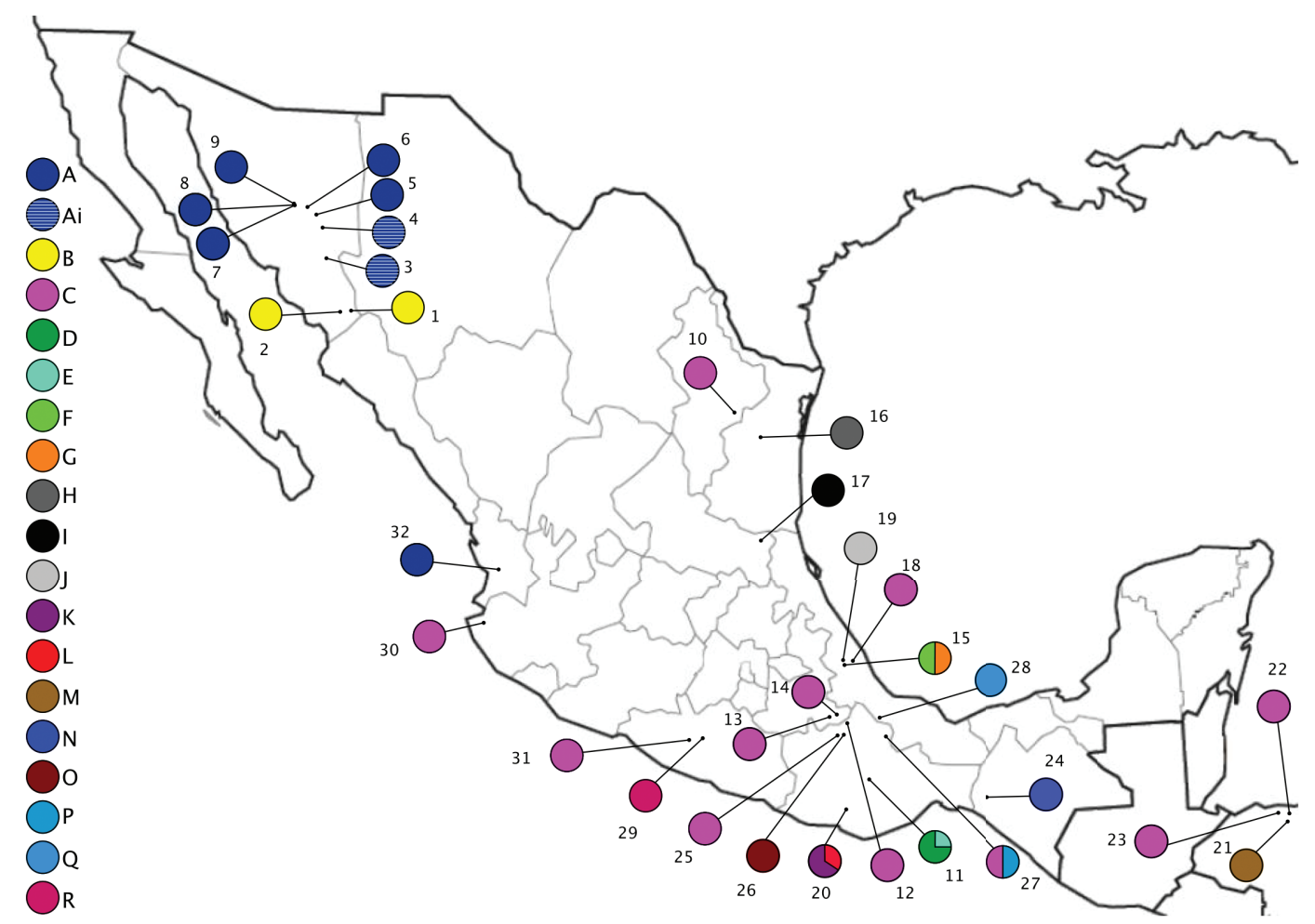

Figure 1. Distribution of 19 haplotypes of the trnL-F spacer recovered from all 14 currently described species of the genus Dioon (haplotypes labeled A-R). Pie charts reflect the proportion of occurrence of each haplotype in each locality. Location numbers correspond to those listed in Table 1.

Geographical distribution of the haplotypes of Dioon sonorense. For the trnL intron and the non-coding region trnL$F$ of the cpDNA of $D$. sonorense, three haplotypes were found among nine populations. Haplotypes A, Ai, and B, corresponded to northern, central, and southern populations, respectively (Figure 1). Haplotype A was found in three populations from Sierra de Mazatán, in El Novillo, and in the population next to the road El Novillo-Bacanora. Haplotype Ai, which was detected in the middle range of distribution, Nuri and Bacanora, was differentiated from haplotype A only by one indel event; however, since indels in mononucleotide repeat regions are not suitable for genealogical analysis due to possible homoplasy biases (Selkoe and Toonen, 2006), haplotypes A and Ai were considered as equal in further analyses. Haplotype B was found in the two southern protected populations: Sierra de Álamos and Choquincahui, and sequences were congruent with those borrowed from GenBank (Specimen A = DQ926776; Specimen B = DQ926777).

Haplotype network. A total of 114 sequences of the trnL intron and $\operatorname{trnL}-F$ region were compiled for the haplotype network. It comprised 77 sequences of Dioon sonorense, six new sequences of other Dioon species, and 31 sequences borrowed from GenBank previously analyzed by González et al. (2008; Table 2). Thirty-two populations among all the
14 species of the genus Dioon were covered. The length of the alignment, excluding the mononucleotide repeat region, was $976 \mathrm{bp}$. In total, 19 haplotypes were detected in all the distribution range of Dioon (Table 3; Figures 1,2). Whereas haplotype B was found exclusively in $D$. sonorense, haplotype A was shared between the northern populations of $D$. sonorense and one sample of D. tomasellii. Haplotype C was detected as shared among eight species, being the most widespread haplotype (Table 2; Figures 1,2). The remaining haplotypes were found exclusively in other species.

\section{Discussion}

An extensive survey throughout nine populations of Dioon sonorense was carried out. Besides the four populations analyzed by González-Astorga et al. (2008, 2009), five new populations analyzed with molecular markers are reported here. The sampling of these nine populations represents a clearer resolution in the identification of intraspecific groups on $D$. sonorense. The analyses revealed low levels of genetic diversity for the trnL intron and $t r n L-F$ intergenic spacer of the cpDNA; however, three geographically structured haplotypes, A, Ai and B, were detected throughout its range of distribution, corresponding to northern, central and southern populations, respectively. Estimated genetic diversity and its conservation implications are discussed below. 


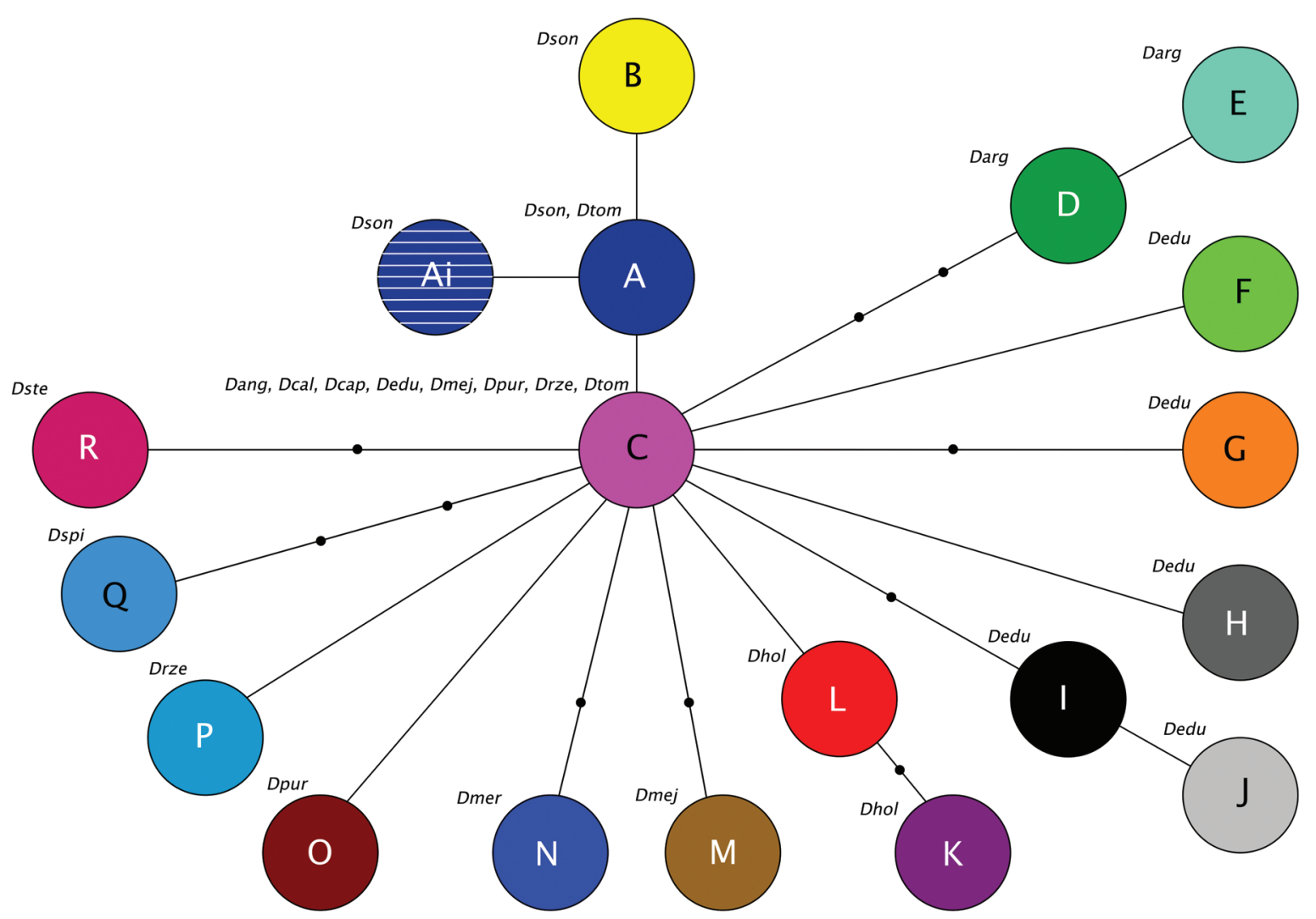

Figure 2. Haplotype network constructed under a criterion of statistical parsimony depicting mutational relationships among haplotypes recovered from $\operatorname{trn} L$ intron and $t r n L-t r n F$ spacer from all 14 current described species of the genus Dioon. Letters as in Figure 1 identify haplotypes. Names of the species where the haplotypes were detected are noted next to the haplotype label: Dang = D. angustifolium, Darg $=D \cdot$ argenteum, Dcal $=D$. califanoi, Dcap $=D$. caputoi, Dedu $=$ D. edule, Dhol $=$ D. holmgrenii, Dmej $=$ D. mejiae, Dmer $=$ D. $m e r o l a e$,

Dpur $=$ D. purpusii, Drze $=$ D. rzedowskii $;$ Dson $=$ D. sonorense, Dspi $=$ D. spinulosum, Dste $=D$. stevensonii, Dtom $=$ D. tomasellii.

Genetic diversity and geographic structure. In a total of $4,115 \mathrm{bp}$ from six non-coding regions of the cpDNA of the endangered cycad species Dioon sonorense, only two sites were detected as variable. Both sites, one transversion and one indel, were found in the $\operatorname{trn} L$ intron and $t r n L-F$ region (978 bp) and allowed the estimation of low levels of genetic variation $\left(H d_{\mathrm{i}}=0.6295, \pi=0.0004\right)$. Values found in $D$. sonorense were similar to those found in the northernmost Asian cycad species Cycas revoluta, in Japan (Hd $=0.641$, $\pi=0.00071$; Kyoda and Setoguchi, 2010). For C. revolu$t a$, the preliminary analyses surveyed a total of $14,130 \mathrm{bp}$ of organelle DNA and only one polymorphic site and one indel were detected, resulting in three haplotypes showing geographic structure. In contrast, higher levels of cpDNA diversity are reported for $C$. taitungensis, a relict endemic species of Taiwan $(H d=0.998, \pi=0.01268)$, resulting in 97 haplotypes (Huang et al., 2001). Variation in the levels of diversity of cpDNA in these species may be due to both demographic and genetic factors.

Because the estimation is done by pairwise comparison, the value of nucleotide diversity might be affected by the presence of common haplotypes (no rare haplotypes were detected at the intraspecific level on Dioon sonorense), therefore, low levels were expected (Nei, 1987). Usually, low values for $\pi$ and $H d$ are interpreted as resulting from recent demographic bottlenecks, followed by a rapid expansion of populations (Avise, 2000). This idea is supported by Tajima's statistical test $(D)$. Tajima's D test evaluates the neutrality of a molecular marker under the assumption of equilibrium conditions (when $\theta-W=\pi$ ). Although the sequences used in this study are from a non-coding region, which is not affected by natural selection, this spacer showed a deviated value (1.10825; not significant, $P>0.10$ ), suggesting that populations may have been affected by historical events, such as demographic bottlenecks (Hedrick, 2005).

The northernmost populations that have haplotype A are located in Sierra de Mazatán. Three localities, one with about 75 individuals and two with more than 100 individuals, are reported here (Table 1). The distance between Rancho La Cueva and Cañada de la Leona is $6 \mathrm{~km}$, which in turn, is $1 \mathrm{~km}$ from Peñón de las Iglesias. Despite their closeness, it is unknown whether gene flow by seed or pollen dispersal 
Table 3. Variable sites of $t r n L$ intron and $\operatorname{trn} L-F$ used to determine haplotypes in genus Dioon (haplotypes labeled A-R). Hap = haplotype, NR= first site of mononucleotide repeat region, dots $\left(^{(}\right)=$same character state as for Hap A, hyphen $(-)=$indel site.

\begin{tabular}{|c|c|c|c|c|c|c|c|c|c|c|c|c|c|c|c|c|c|c|c|c|c|c|c|c|c|c|c|c|}
\hline \begin{tabular}{l} 
Hap \} $\\
{\text { site }}$ & 8 & 34 & 36 & 42 & 119 & 122 & 188 & 223 & 302 & 330 & 331 & 3773 & 391 & 445 & 480 & 494 & 558 & 572 & 574 & 636 & NR & 657 & 715 & 848 & 850 & 895 & 932 & 939 \\
\hline Hap A & A & $C$ & A & $\mathrm{T}$ & $\mathrm{T}$ & C & A & A & $\mathrm{T}$ & $\mathrm{T}$ & $C$ & $\mathrm{~T}$ & G & $\mathrm{T}$ & A & A & C & $\mathrm{T}$ & $\mathrm{T}$ & C & A & $\mathrm{T}$ & G & $\mathrm{T}$ & C & - & $\mathrm{T}$ & $\mathrm{T}$ \\
\hline Hap Ai & $\cdot$ & . & $\cdot$ & $\cdot$ & $\cdot$ & $\cdot$ & $\cdot$ & $\cdot$ & $\cdot$ & $\cdot$ & $\cdot$ & $\cdot$ & $\cdot$ & $\cdot$ & $\cdot$ & $\cdot$ & $\cdot$ & $\cdot$ & $\cdot$ & $\cdot$ & - & . & $\cdot$ & $\cdot$ & $\cdot$ & $\cdot$ & $\cdot$ & $\cdot$ \\
\hline Hap B & $\cdot$ & $\cdot$ & $\cdot$ & $\cdot$ & $\cdot$ & $\cdot$ & $\cdot$ & $\cdot$ & $\cdot$ & $\cdot$ & $\cdot$ & $\cdot$ & $\cdot$ & $\cdot$ & $\cdot$ & $\cdot$ & $\cdot$ & $\cdot$ & $\cdot$ & A & $\cdot$ & $\cdot$ & $\cdot$ & $\cdot$ & $\cdot$ & $\cdot$ & $\cdot$ & $\cdot$ \\
\hline Hap C & $\cdot$ & · & $\cdot$ & $\cdot$ & $\cdot$ & $\cdot$ & C & $\cdot$ & $\cdot$ & $\cdot$ & $\cdot$ & $\cdot$ & $\cdot$ & $\cdot$ & $\cdot$ & & $\cdot$ & $\cdot$ & . & $\cdot$ & $\cdot$ & $\cdot$ & $\cdot$ & $\cdot$ & . & $\cdot$ & $\cdot$ & $\cdot$ \\
\hline Hap D & $\cdot$ & $\cdot$ & $\cdot$ & $\cdot$ & $\cdot$ & $\cdot$ & C & $\cdot$ & $\cdot$ & C & $\mathrm{T}$ & $\cdot$ & $\cdot$ & $\cdot$ & $\cdot$ & $\cdot$ & $\mathrm{T}$ & $\cdot$ & $\cdot$ & $\cdot$ & - & $\cdot$ & $\cdot$ & $\cdot$ & $\cdot$ & $\cdot$ & $\cdot$ & $\cdot$ \\
\hline Hap E & $\cdot$ & $\cdot$ & $\cdot$ & $\cdot$ & $\cdot$ & . & $\mathrm{C}$ & . & $\cdot$ & C & $\mathrm{T}$ & $\cdot$ & $\cdot$ & C & $\cdot$ & . & $\mathrm{T}$ & $\cdot$ & $\cdot$ & $\cdot$ & - & $\cdot$ & $\cdot$ & $\cdot$ & . & $\cdot$ & $\cdot$ & . \\
\hline Hap F & $\cdot$ & $\cdot$ & $\cdot$ & $\mathrm{C}$ & $\cdot$ & . & C & $\cdot$ & $\cdot$ & . & $\cdot$ & $\cdot$ & & $\cdot$ & $\cdot$ & & $\cdot$ & $\cdot$ & . & $\cdot$ & - & $\cdot$ & $\cdot$ & $\cdot$ & $\cdot$ & $\cdot$ & $\cdot$ & \\
\hline Hap G & $\cdot$ & . & $\cdot$ & $\cdot$ & $\cdot$ & . & C & . & . & . & . & . & . & . & $\mathrm{T}$ & - & . & . & . & . & $\cdot$ & . & $\cdot$ & . & . & . & . & \\
\hline Hap H & $\cdot$ & $\cdot$ & $\cdot$ & $\cdot$ & $\cdot$ & $\cdot$ & C & $\cdot$ & C & $\cdot$ & $\cdot$ & $\cdot$ & $\cdot$ & $\cdot$ & $\cdot$ & & $\cdot$ & $\cdot$ & . & $\cdot$ & $\cdot$ & $\cdot$ & $\cdot$ & $\cdot$ & . & $\cdot$ & $\cdot$ & \\
\hline Hap I & $\cdot$ & $\cdot$ & $\cdot$ & $\cdot$ & $\cdot$ & $\cdot$ & C & $\cdot$ & $\cdot$ & & $\cdot$ & $\cdot$ & $\cdot$ & $\cdot$ & $\cdot$ & $\cdot$ & $\cdot$ & C & $\cdot$ & & $\cdot$ & $\cdot$ & & C & . & $\cdot$ & $\cdot$ & . \\
\hline Hap J & $\cdot$ & . & $\cdot$ & $\cdot$ & $\cdot$ & $\mathrm{T}$ & C & & $\cdot$ & . & . & & & $\cdot$ & . & & $\cdot$ & C & $\cdot$ & . & $\cdot$ & $\cdot$ & . & C & . & . & . & \\
\hline Hap K & $\cdot$ & . & $\cdot$ & $\cdot$ & $\cdot$ & $\cdot$ & C & & $\cdot$ & . & . & C & & $\cdot$ & $\cdot$ & & $\cdot$ & $\cdot$ & C & $\cdot$ & - & G & $\cdot$ & $\cdot$ & $\cdot$ & $\cdot$ & $\cdot$ & \\
\hline Hap L & $\cdot$ & $\cdot$ & $\cdot$ & $\cdot$ & $\cdot$ & $\cdot$ & C & & $\cdot$ & $\cdot$ & $\cdot$ & C & $\cdot$ & $\cdot$ & $\cdot$ & & $\cdot$ & $\cdot$ & $\cdot$ & $\cdot$ & - & $\cdot$ & $\cdot$ & $\cdot$ & $\cdot$ & $\cdot$ & $\cdot$ & \\
\hline Hap M & $\cdot$ & A & C & $\cdot$ & $\cdot$ & $\cdot$ & C & $\cdot$ & $\cdot$ & & $\cdot$ & $\cdot$ & $\cdot$ & $\cdot$ & $\cdot$ & $\cdot$ & $\cdot$ & & $\cdot$ & & - & $\cdot$ & & $\cdot$ & $\cdot$ & $\cdot$ & $\cdot$ & $\cdot$ \\
\hline Hap N & $\cdot$ & $\cdot$ & $\cdot$ & $\cdot$ & $\cdot$ & $\cdot$ & C & G & & & $\cdot$ & $\cdot$ & $\cdot$ & $\cdot$ & $\cdot$ & $\cdot$ & $\cdot$ & & $\cdot$ & & $\cdot$ & $\cdot$ & A & $\cdot$ & $\cdot$ & $\cdot$ & $\cdot$ & $\cdot$ \\
\hline Hap O & $\cdot$ & $\cdot$ & $\cdot$ & . & $\cdot$ & $\cdot$ & C & $\cdot$ & $\cdot$ & $\cdot$ & $\cdot$ & $\cdot$ & $\mathrm{T}$ & $\cdot$ & . & & $\cdot$ & . & $\cdot$ & . & $\cdot$ & $\cdot$ & $\cdot$ & . & $\cdot$ & $\cdot$ & $\cdot$ & $\cdot$ \\
\hline Hap P & $\cdot$ & $\cdot$ & $\cdot$ & $\cdot$ & $\cdot$ & $\cdot$ & $\mathrm{C}$ & & $\cdot$ & $\cdot$ & $\cdot$ & & & $\cdot$ & $\cdot$ & & $\cdot$ & $\cdot$ & $\cdot$ & $\cdot$ & - & $\cdot$ & $\cdot$ & $\cdot$ & $\cdot$ & $\mathrm{T}$ & $\cdot$ & \\
\hline Hap Q & $C$ & $\cdot$ & $\cdot$ & $\cdot$ & $\cdot$ & $\cdot$ & C & & $\cdot$ & $\cdot$ & $\cdot$ & & & $\cdot$ & $\cdot$ & & $\cdot$ & $\cdot$ & . & $\cdot$ & $\cdot$ & $\cdot$ & $\cdot$ & $\cdot$ & $\mathrm{T}$ & $\cdot$ & $\cdot$ & G \\
\hline Hap R & $\cdot$ & & $\cdot$ & $\cdot$ & $C$ & $\cdot$ & C & $\cdot$ & $\cdot$ & $\cdot$ & $\cdot$ & $\cdot$ & $\cdot$ & . & . & $\cdot$ & $\cdot$ & . & . & $\cdot$ & . & . & $\cdot$ & . & $\cdot$ & $\cdot$ & $C$ & $\cdot$ \\
\hline
\end{tabular}
\end{tabular}

occurs within this set of populations. For that purpose, other molecular markers, such as microsatellites, would give a better resolution (Selkoe and Toonen, 2006). In addition, haplotype A was also identified in El Novillo and next to the road El Novillo-Bacanora. In these localities, only two and seven individuals were found, respectively. There, local dwellers associate this low number of individuals to illegal collection for ornamental use and for the preparation of alcoholic beverages. Based on field observations of populations that share haplotype A, populations from the Sierra de Mazatán seem to be well conserved and their difficult accesses keep them largely away from illegal collectors. However, demographic studies are needed to know the structure of these populations, patterns of recruitment, and demographic tendencies.

Haplotype Ai occurs in populations from Bacanora and Nuri. The population of Bacanora is distributed only in the northern face of a mountain, where local people have commented that the number of individuals has decreased while elements of "monte mojino" (represented by thornscrub vegetation and Prosopis spp.) have been colonizing during the past 40 years. The population of Nuri was small, as only eight individuals were found next to a rural road. In this locality, signs of a recent extraction of plants were observed, this being a common practice, according to local testimonies. No significant geographical barriers exist between the ranges of distribution of haplotypes $\mathrm{A}$ and $\mathrm{Ai}$; moreover, although the molecular marker employed in this study separates haplotypes A and Ai by one indel event in a mo- nonucleotide repeat region, such difference is not suitable for genealogical analyses due to possible homoplasy biases (Selkoe and Toonen, 2006). For these reasons, haplotypes A and Ai may be considered a unique evolutionary unit.

Haplotype B was found in the two southern populations analyzed in this study. Both populations are protected within the range of the Área de Protección de Flora y Fauna Sierra de Âlamos-Río Cuchujaqui (CONANP, 2013). The local people from Ejido Choquincahui have been involved in the conservation of the nearby populations of Dioon sonorense. However, the demographic study by Álvarez-Yépiz et al. (2011) suggests a low long-term persistence probability. Since low number of adults, low quality of habitat, and low fecundity and recruitment were detected in that study, more management measures and a greater effort to avoid illegal collections is necessary for most of these populations. On the other hand, it is uncertain whether gene flow exists among this set of populations. A larger number of populations analyzed with different molecular markers would give a better resolution in the detection of important spots of genetic diversity in this conservation area.

Genealogy and species relationships. The data matrix which merged all the Dioon species consisted of 114 sequences of the trnL-F region of cpDNA. Thirty-one sequences used in this analysis were produced by the phylogenetic work of González et al. (2008); however, genealogical issues were not discussed in that publication. In that study, most of the resolution of topologies was obtained from the variation of 
internal transcribed spacer (ITS) of ribosomal DNA, while $\operatorname{trn} L-F$ region showed low levels of variation. Although the variation of $t r n L-F$ region was unable to provide a concrete resolution on the relationships within a phylogenetic tree, its representation as haplotypes on a geographical setting (Figure 1) and on a haplotype network (Figure 2) permitted to formulate general inferences about the genealogy of the genus Dioon.

It is thought that the center of diversification of the current Dioon species was in southern Mexico (Moretti et al., 1993; González et al., 2008; Moynihan, 2008), and very recent migration events have been proposed as a result of successful seed dispersal during interglacial periods of the Pleistocene (Gregory and Chemnick, 2004). This idea seems to be supported by the paleoclimatic characterization of Toledo (1982), and suggests that the Sierra Madre mountain chains have played an important role in the migration of communities that are currently distributed within areas considered as Pleistocene refugia (Sauer, 1988; Contreras-Medina and Luna-Vega, 2007).

Haplotype A was detected in samples from populations of Dioon sonorense and D. tomasellii which were uncovered in the phylogenetic analysis by González et al. (2008). This haplotype sharing indicates a close relationship between the species, being congruent with the taxonomic description for the taxa (de Luca et al., 1984) and the phylogenetic analysis at genus level, in which these species are shown as sister species (González et al., 2008; Moynihan, 2008). Haplotype C was detected as an ancestral haplotype and was found shared among eight species on a wide distributional range (Figure 1, 2). Recent divergence or ancestral polymorphism might explain this phenomenon, but more samples and different molecular markers are necessary to assess these probable scenarios. Though this analysis represents a first attempt in understanding the genealogy of the entire genus Dioon, a deeper sampling scheme including more populations of all species is necessary in order to obtain a robust resolution.

Conservation of populations of Dioon sonorense. Since haplotypes A and B correspond to lineages that have a distinct evolutionary potential, at least these two sets of populations should be considered as independent ESUs to be included in conservation plans (Moritz, 1994). Although each population represents important spots of genetic diversity, some of them (e.g. El Novillo, El Novillo-Bacanora, and Nuri) seem to be senescent due to anthropogenic impact. In the northern distribution, populations from the Sierra de Mazatán should be conserved, and more studies regarding demography and genetic diversity are necessary to support its importance. Currently, the Sierra de Mazatán is proposed as an area for conservation as Área de Protección de Flora y Fauna, under the name of Sierra Huérfana, but its status has still not been approved by the Federal Govern- ment (CONANP, 2013). Like the populations from Sierra de Mazatán, the locality in Bacanora is relatively isolated, and thus, illegal collection seems to be infrequent; however, its preservation is recommended and the demography should be studied to determine its current status and long term-persistence. Regarding the southern populations, although they are protected, more effective management plans should be performed for the preservation of $D$. sonorense. Plans that include the collaboration of local people, like the one that was applied with the species D. edule in Veracruz, should be promoted (Vovides and Iglesias, 1994).

Despite the short length of the non-coding region $\operatorname{trn} L-F$ of the cpDNA of Dioon sonorense (978 bp), it implies the level of variation through 4,115 bp and showed enough variation to distinguish geographical structure at the intraspecific level. For that reason, using it as a concise DNA marker to infer the origin of individuals of $D$. sonorense seems applicable. The original localities of individuals deposited in collections, as well as individuals illegally collected, would be roughly traceable by the employment of this molecular marker.

\section{Conclusions}

In order to include different ESU for the conservation of the species Dioon sonorense, this study proposes the conservation of populations in the Sierra de Mazatán, and while the southern populations are distributed within an official protected area, more efficient efforts are needed for the protection of these populations from anthropogenic impact. This work represents an example of how a genealogical perspective can be applied to the identification of evolutionary units to address both conservation and evolutionary issues on Mexican cycads.

\section{Acknowledgments}

Special thanks to José F. Martinez and Román Rodríguez for field and lab support, and Haydeé Zazueta for lab assistance. Thanks to Dr. Andrew Vovides and Dr. Jorge González-Astorga for providing samples from the "Colección Nacional de Cycadas", INECOL. We appreciate the criticisms provided by three anonymous reviewers who gave invaluable comments that improved the final version of this article. First author acknowledges support from MEXT, Japan.

\section{Literature cited}

Álvarez-Yépiz J.C., Dovčiak M. and Búrquez A. 2011. Persistence of a rare ancient cycad: Effects of environment and demography. Biological Conservation 144:122-130.

Avise J.C. 2000. Phylogeography: The History and Formation of Species. Harvard University Press, Cambridge.

Bonta M.A., Flores P.O., Graham D., Haynes J. and Sandoval G. 2006. Ethnobotany and conservation of tiusinte (Dioon mejiae 
Standl. \& L.O. Williams, Zamiaceae) in Northeastern Honduras. Journal of Ethnobiology 26:228-257.

Cabrera-Toledo D., González-Astorga J. and Vovides A.P. 2008. Heterozygote excess in ancient populations of the critically endangered Dioon caputoi (Zamiaceae, Cycadales) from central Mexico. Botanical Journal of the Linnean Society 158:436447.

Cafasso D., Cozzolino S., Caputo P. and de Luca P. 2001. Maternal inheritance of plastids in Encephalartos Lehm. (Zamiaceae, Cycadales). Genome 44:239-241.

Chiang T.Y., Schaal B.A. and Peng C.I. 1998. Universal primers for amplification and sequencing a noncoding spacer between the atp B and $r b c \mathrm{~L}$ genes of chloroplast DNA. Botanical Bulletin of Academy Sinica 39:245-250.

Clement M., Posada D. and Crandall K.A. 2000. TCS: a computer program to estimate gene genealogies. Molecular Ecology 9:1657-1659.

CONANP. Comisión Nacional de Áreas Naturales Protegidas. 2013. Anexo 8. Claves de regiones prioritarias para PROCODES por Dirección Regional. <http://www.conanp.gob.mx/ temp/ANEXO\%208.pdf> (accessed August 7, 2013).

Contreras-Medina R. and Luna-Vega I. 2007. Species richness, endemism and conservation of Mexican gymnosperms. Biodiversity and Conservation 16:1803-1821.

de Luca P., Sabato S., Vázquez T.M. 1984. Dion tomasellii (Zamiaceae), a new species with two varieties from western Mexico. Brittonia 36:223-227.

Doyle J.J. and Doyle J.L. 1987. A rapid DNA isolation procedure for small quantities of fresh leaf tissue. Phytochemical Bulletin 19:11-15.

González D., Vovides A.P. and Bárcenas C. 2008. Phylogenetic relationships of the Neotropical genus Dioon (Cycadales, Zamiaceae) based on nuclear and chloroplast DNA sequence data. Systematic Botany 33:229-236.

González-Astorga J., Vovides A.P., Cabrera-Toledo D. and Nicolalde-Morejón F. 2009. Diversity and genetic structure of the endangered cycad Dioon sonorense (Zamiaceae) from Sonora, Mexico: Evolutionary and conservation implications. Biochemical Systematics and Ecology 36:891-899.

González-Astorga J., Vovides A.P., Ferrer M.M. and Iglesias C. 2003. Population genetics of Dioon edule Lindl. (Zamiaceae, Cycadales): biogeographical and evolutionary implications. Biological Journal of the Linnean Society 80:457-467.

González-Astorga J., Vovides A.P., Cruz-Angón A., Octavio-Aguilar P. and Iglesias C. 2005. Allozyme variation in the three extant populations of the narrowly endemic cycad Dioon angustifolium Miq. (Zamiaceae) from North-eastern Mexico. Annals of Botany 95:999-1007.

González-Astorga J., Vergara-Silva F., Vovides A.P., NicolaldeMorejón F., Cabrera-Toledo D. and Pérez-Farrera M.A. 2008. Diversity and genetic structure of three species of Dioon Lindl. (Zamiaceae, Cycadales) from the Pacific Seaboard of Mexico. Biological Journal of the Linnean Society 94:765-776.

Google Inc. 2013. Google Earth (Version 7). <http://www.google. com/earth/download/ge/agree.html> (accessed May 4, 2013).

Gregory T.J. and Chemnick J. 2004. Hypotheses on the relationship between biogeography and speciation in Dioon (Zamiaceae). In: Walters T. and Osborne R. Eds. Cycad Classification: Concepts and Recommendations, pp. 137-148, CABI Publishing, Cambridge.
Hedrick P.W. 2005. Genetics of Populations. $3^{\text {rd }}$ edition. Jones and Bartlett Publishers, Boston.

Hall T.A. 1999. BioEdit: a user-friendly biological sequence alignment editor and analysis program for Windows 95/98/NT. Nucleic Acids Symposium Series 41:95-98.

Huang S., Chiang Y.C., Schaal B.A., Chou C.H. and Chiang T.Y. 2001. Organelle DNA phylogeography of Cycas taitungensis, a relict species in Taiwan. Molecular Ecology 10:2669-2681.

IUCN. International Union for Conservation of Nature. 2013. IUCN Red List of Threatened Species. Version 2013.1 <www. iucnredlist.org > (accessed August 10, 2013).

Kyoda S. and Setoguchi H. 2010. Phylogeography of Cycas revoluta Thunb. (Cycadaceae) on the Ryukyu Islands: very low genetic diversity and geographical structure. Plant Systematics and Evolution 288:177-189.

Lahaye R., van der Bank M., Bogarin D., Warner J., Pupulin F., Gigot G., Maurin O., Duthoit S., Barraclough T.G. and Savolainen V. 2008. DNA barcoding the floras of biodiversity hotspots. Proceedings of the National Academy of Sciences of the United States of America 105:2923-2928.

Librado P. and Rozas J. 2009. DnaSP v5: A software for comprehensive analysis of DNA polymorphism data. Bioinformatics 25:1451-1452.

Matocq M.D. and Villablanca F.X. 2001. Low genetic diversity in an endangered species: recent or historic pattern? Biological Conservation 98:61-68.

Moretti A., Caputo P., Cozzolino S., de Luca P., Gaudio L., Siniscalco G.G., Stevenson D.W. 1993. A phylogenetic analysis of Dioon (Zamiaceae). American Journal of Botany 80:204-214.

Moritz C. 1994. Defining 'evolutionarily significant units' for conservation. Trends in Ecology and Evolution 9:373-375.

Moynihan J. 2008. Dioon Lindl. (Zamiaceae): Perspectives from phylogeny and a population genetic study of D. edule. Ph.D. Dissertation, Florida International University. Miami, 135 pp.

Nei M. 1987. Molecular Evolutionary Genetics. Columbia University Press, New York.

Osborne R., Calonje M.A., Hill K.D., Stanberg L. and Stevenson D.W. 2012. The world list of cycads. In: Stevenson D.W., Osborne R., Sidney A. and Blake T. Eds. Proceedings of Cycad 2008: the 8th International Conference on Cycad Biology (CYCAD 2008) Ed. Memoirs of the New York Botanical Garden 106:480-510.

Piñero D., Caballero-Mellado J., Cabrera-Toledo D., Canteros C.E., Casas A., Castañeda S.A., Castillo A., Cerritos R., Chassin-Noria O., Colunga-GarcíaMarín P., Delgado P., Díaz-Jaimes P., Eguiarte L.E., Escalante A.E., Espinoza B., Fleury A., Flores R.S., Fragoso G., González-Astorga J., Islas V.V., Martínez E., Martínez F., Martínez-Castillo J., Mastretta Y.A., Medellín R., Medrano-González L., Molina-Freaner F., Morales V.B., Murguía V.A., Payró de la C.E., Reyes M.M.R., Robles S.M.R., Rodríguez-Arellanes G., Rojas B.L., Romero-Martínez R., SahazaCardona J.H, Salas L.R., Sciutto E., Baker C.S., Schramm U.Y., Silva C., Souza V., Taylor M.L., Urbán R.J., Uribe-Alcocer M., Vázquez C.M.J., Vázquez-Domínguez E., Vovides A.P., Wegier A., Zaldívar R.A. and Zúñiga G. 2008. La diversidad genética como instrumento para la conservación y el aprovechamiento de la biodiversidad: estudios en especies mexicanas. In: CONABIO. Capital Natural de México, Vol. I: Conocimiento actual de la Biodiversidad. pp. 437-494, Comisión Nacional para el Conocimiento y Uso de la Biodiversidad. México, D.F. 
Ravi V., Khurana J.P., Tyagi A.K. and Khurana P. 2008. An update on chloroplast genomes. Plant Systematics and Evolution 271:101-122.

Rosenberg N.A. and Nordborg M. 2002. Genealogical trees, coalescent theory and the analysis of genetic polymorphisms. $\mathrm{Na}$ ture Reviews Genetics 3:380-390.

Sang T., Crawford D.J. and Stuessy T.F. 1997. Chloroplast DNA phylogeny, reticulate evolution, and biogeography of Paeonia (Paeoniaceae). American Journal of Botany 84:1120-1136.

Sauer J.D. 1988. Plant Migration: The Dynamics of Geographic Pattering in Seed Plant species. University of California Press, Berkeley.

Selkoe K.A. and Toonen R.J. 2006. Microsatellites for ecologists: a practical guide to using and evaluating microsatellite markers. Ecology Letters 9:615-629.

SEMARNAT. Secretaría de Medio Ambiente y Recursos Naturales. 2010. Norma Oficial Mexicana NOM-059-SEMARNAT2010. Protección ambiental-Especies nativas de México de flora y fauna silvestres-Categorías de riesgo y especificaciones para su inclusión, exclusión o cambio-Lista de especies en riesgo <http://www.profepa.gob.mx/innovaportal/file/435/1/NOM 059_SEMARNAT_2010.pdf> (accessed August 10, 2013).

Shaw J., Lickey E.B., Beck J.T., Farmer S.B., Liu W., Miller J., Siripun K.C., Winder C.T., Schilling E.E. and Small R.L. 2005. The tortoise and the hare II: Relative utility of 21 noncoding chloroplast DNA sequences for phylogenetic analysis. American Journal of Botany 92:142-166.

Taberlet P. and Bouvet J. 1994. Mitochondrial DNA polymorphism, phylogeography, and conservation genetics of the brown bear Ursus arctos in Europe. Proceedings of the Royal Society, B Series, Biological Sciences 255:195-200.

Taberlet P., Gielly L., Pautou G. and Bouvet J. 1991. Universal primers for amplification of three non-coding regions of chloroplast DNA. Plant Molecular Biology 17:1105-1109.

Tate J.A. and Simpson B.B. 2003. Paraphyly of Tarasa (Malvaceae) and diverse origins of the polyploid species. Systematic Botany 28:723-737.

Thompson J.D., Gibson T.J., Plewniak F., Jeanmougin F. and Higgins D.G. 1997. The CLUSTAL_X Windows interface: flexible strategies for multiple sequence alignment aided by quality analysis tools. Nucleic Acids Research 25:4876-4882.

Toledo V.M. 1982. Pleistocene changes in vegetation in tropical Mexico. In: Prance G.T. Ed. Biological Diversification in the Tropics. Proceedings of the Fifth International Symposium of the Association for Tropical Biology, pp. 93-111, Columbia University Press, New York.

Vovides A.P. and Iglesias C.G. 1994. An integrated conservation strategy for the cycad Dioon edule Lindl. Biodiversity and Conservation 3:137-141.

Whitelock L.M. 2002. The Cycads. Timber Press, Portland.

Received: August 28th, 2013

Accepted: December 22nd, 2013 


\section{Conservation genetics of Dioon SONORENSE}

\section{Appendix 1}

Chloroplast DNA regions examined and primers used in this study.

\begin{tabular}{|c|c|c|c|c|}
\hline $\begin{array}{l}\text { Chloroplast } \\
\text { region }\end{array}$ & $\begin{array}{l}\text { Length of PCR } \\
\text { products (bp) }\end{array}$ & Primers & Primer sequence $\left(5^{\prime}-3^{\prime}\right)$ & Primer source \\
\hline \multirow[t]{2}{*}{$a t p B-r b c L$} & \multirow[t]{2}{*}{765} & $\operatorname{atp} B-1$ & ACA TCK ART ACK GGA CCA ATA A & \multirow[t]{2}{*}{ Chiang et al., 1998} \\
\hline & & $r b c L-1$ & AAC ACC AGC TTT RAA TCC AA & \\
\hline \multirow[t]{2}{*}{ atpF-H } & \multirow[t]{2}{*}{565} & atpF & ACTCGCACACACTCССТTTCC & \multirow[t]{2}{*}{ Lahaye et al., 2008} \\
\hline & & atpH & GCTTTTATGGAAGCTTTAACAAT & \\
\hline \multirow[t]{2}{*}{$\operatorname{trnT-trnL}$} & \multirow[t]{2}{*}{456} & $\mathrm{a}$ & CAT TAC AAA TGC GAT GCT CT & \multirow[t]{2}{*}{ Taberlet et al., 1991} \\
\hline & & $\mathrm{b}$ & TCT ACC GAT TTC GCC ATA TC & \\
\hline \multirow[t]{2}{*}{ Intron trnL + trnL-F } & \multirow[t]{2}{*}{978} & c & CGA AAT CGG TAG ACG CTA CG & \multirow[t]{2}{*}{ Taberlet et al., 1991} \\
\hline & & $f$ & ATT TGA ACT GGT GAC ACG AG & \\
\hline \multirow[t]{2}{*}{ psbA-trnH } & \multirow[t]{2}{*}{582} & $p s b A 3^{\prime} f$ & GTTATGCATGAACGTAATGCTC & \multirow{2}{*}{$\begin{array}{l}\text { Sang et al., 1997; } \\
\text { Tate and Simpson, } 2003\end{array}$} \\
\hline & & $\operatorname{trnH}$ & CGC GCA TGG TGG ATT CAC AAT CC & \\
\hline \multirow[t]{2}{*}{ rp/20-rps12 } & \multirow[t]{2}{*}{770} & $r p L 20$ & CGY YAY CGA GCT ATA TAT CC & \multirow[t]{2}{*}{ Shaw et al., 2005} \\
\hline & & 5'rpS12 & ATT AGA AAN TCA AGA CAG CCA AT & \\
\hline
\end{tabular}

